\title{
History of development and perspectives of using of achievments of psychological science in combat to criminality
}

Abstract: It is considered genesis and perspectives of use of the psychological knowledge in combat to criminality, there are given suggestions on changing and supplementing of the legislation.

Structure of use of psychological knowledge in criminal process is researched.

Keywords: psychological knowledge; criminal proceedings; structure; intergrative criminalistical tactics.

İnsan fəaliyyətinin elə bir sahəsi yoxdur ki, psixoligiya elminin müdaxiləsi onu müşaiyət etməsin.

Cinayətkarlıqla mübarizədə psixologiya elminin nailiyyətlərindən istifadə edilməsinin zəruriliyi ilə bağlı fikirlərin iki əsrdən çox tarixi var (K. Ekartsqauzen, N.Şauman).

Hüquqi nəzəriyyə və təcrübə həmişə psixologiyanın nailiyyətlərindən istifadə edərək zənginləşmişdir. Həyat özü hüquqşünasları məcbur edir ki, psixologiyaelminin müddəalarından istifadə edərək, müxtəlif tədqiqatlar aparsınlar,istintaq və məhkəmə təcrübəsini ümumiləşdirərək,cinayətkarlıqla mübarizə üçün tövsiyyələr hazırlasınlar.

Fikrimizcə, cinayətin subyektiv cəhəti müəyyən edilərkən cinayətin törədilməsi ilə əlaqədar şəxsin psixi fəaliyyəti tədqiq olunmalıdır,yəni təqsirlilik nəzəriyyəsini psixologiyanın da predmeti hesab etmək olar.Cinayət prosesi

\footnotetext{
- Abdurahmanov Shair Sheykhali oglu - a senior lecturer of National Aviation Academy (Azerbaijan). E-mail: mopi_sid@yahoo.com
} 
elmində məhkəmə sübutları, sübutetmə fəaliyyətinin həyata keçirilməsi,psixologiyanın müddəalarından istifadə etmədən mümkün deyil.

Kriminalistikanın taktika hissəsi tam,kriminalistik metodikanın isə bir hissəsi psixologiyanın müddəalarına əsaslanır.

Hüquq ədəbiyyatında bəzi alimlərin fikrinə görə,kriminalistik taktikanın inkişafını psixologiyanın müddəalarından istifadə etmədən təsəvvür etmək olmaz. ${ }^{1}$

Beləliklə,ümumi psixologiya elminin yaranması və inkişafı,hüquqi psixologiya elminin formalaşmasına təkan vermişdir.

Məhkəmə psixologiyası elminin yaranması və inkişafı tarixinə nəzər salaq.Hələ XYIII əsrin axırlarında alimlərin əsərlərində ${ }^{2}$ bəzi hüquqi anlayışların psixoloji tərəflərinin açıqlanmasına cəhd edilmişdir.XIX əsrin 30-cu illərinədək elmi ədəbiyyatda cinayətkarların şəxsiyyətinin öyrənilməsilə bərabər,təqsir və cinayət mühakimə icraatına aid olan digər məsələlər işıqlandırılmışdır. ${ }^{3}$ Lakin bundan sonra uzun müddət bu sahədə hər hansı tədqiqatlar aparılmamışdır.

Yalnız 1834-cü ildə Almaniyada «Систематический указатель литературы по врачебной и криминальной психологии» adlı təlimat-göstərici hazırlanıb nəşr edilmişdir. Belə bir təlimat-göstəricinin nəşri bizə güman etməyə əsas verir ki, o dövrdə kriminal psixologiyacinayətkarın psixologiyası kimi qiymətləndirilirdi. Әvvəllər psixologiyanın hüquqi sahələrdə tətbiqi problemləriməhkəmə təbabəti sahəsində olan əsərlərdə də öz əksini tapırdı.Yalnız sonradan bu problemlərlə hüquqşünaslar və psixoloqlar məşğul olmağa başlamışlar.

XIX əsrin axırlarında kriminal psixologiyanın predmetinin müəyyən edilməsi üçün bir neçə əsərlər yazılmışdır.Bir qrup alimlər bu fenomenin predmetinə məhkəmə işinin psixologiyasını,cinayətkarlığın və cəzanın

\footnotetext{
${ }^{1}$ Korneyeva L.M., Vasilyev A.N., Yakubovich N.A. and others

${ }^{2}$ K.Ekarthausen On necessity psychological knowledge upon discussion of crimes. I. Shauman. Thoughts on criminal psychology

${ }^{3}$ N. Gofbauer Psychology in its main applications to judicial life.
} 
psixologiyasını aid etmişlər. ${ }^{4}$ Başqa bir qrup alimlər isə kriminal-psixologiyanın predmetinə cinayət mühakimə icraatının bütün predmetlərini daxil etmişlər. ${ }^{5}$

$\mathrm{XX}$ əsrin əvvəllərindən bu sahədə çoxlu sayda elmi fikirlər, nəşr olunmuş əsərlərdə öz əksini tapmışdır. Onların əksəriyyətində cinayət mühakimə icraatının bütün mərhələlərdə psixologiya elminin rolunun zəruri olması barədə fikirlər irəli sürülmüşdür.

Yalan ifadə verən şəxslərin ifşası üçün psixoloji təsir metodlarının hazırlanması məhkəmə psixologiyasının digər istiqaməti olmaqla bərabər,həmçinin yalan ifadənin ifşa edilməsini müəyyən etmək üçün Amerika psixoloqlarının və hüquqşünaslarının ixtira etdikləri cihazlar təcrübədə tətbiq olunur (laydedektor, poliqraf).

Psixologiya elminin formalaşmasının digər istiqaməti məhkəmə-psixoloji ekspertizaların təşkili və həyata keçirilməsidir. Belə ki,hələ XIX əsrin əvvəllərində hüquq ədəbiyyatında proses iştirakçılarının tibbi-psixoloji müayinəsi üçün mütəxəssis-psixoloqun köməyindən istifadə edilməsinin zəruriliyi barədəfikir irəli sürülmüşdür. ${ }^{6}$

$\mathrm{XX}$ əsrin əvvəllərində tətbiqi psixologiyanın istiqamətlərindən biri olan və formalaşan əməyin psixologiyası elminin "Psixotexnika" adlanan sahəsi məhkəmə fəaliyyətini də öyrənirdi.Həkimlərin, müstəntiqlərin və digər proses iştirakçılarının peşəkar hazırlığ prosesində onların şəxsi keyfiyyətlərinin öyrənilməsi işinin təşkili üçün tövsiyyələrin hazırlanması kimi vəzifələr qarşıya qoyulmuşdur.Alman alimi Mönsterberqer 1914-cü ildə çapdan çıхmış «Основы психотехники» əsərində psixologiyanın hüquqi fəaliyyətdə tətbiqinə ayrıca bir fəsil həsr etmişdir.

XX əsrin ortalarında Avropanın müxtəlif ölkələrində məhkəmə psixologiyası sahəsində bir sıra tədqiqiatlar aparılmış və elmi əsərlər çap olunmuşdur. ${ }^{7}$ Həmin əsərlərdə məhkəmə psixologiyasının bəzi problemləri barədə təhlillər aparılmışdır.

\footnotetext{
${ }^{4}$ Y. Fridrix, F. Vulnen, P. Kaufman

${ }^{5}$ Shtern, Marbe, Klapered

${ }^{6}$ Vladimirov L.E. Psychologca 1 researh in criminal proceedings

${ }^{7}$ Italian scientist E. Alitavillan "Forensic psychology", almin alimin "Guilt. Deception. Sexuality", English psychologists G. Berton "Applied psychology" and F. Berren "Practical psychology", Belgium criminalist F. Luvajıttin "Psychology and crime", American writer G. Duduçin "Psychology for
} 
Rusiyada psixologiyanın hüquq elmləri ilə uzlaşması məsələsi XIX əsrin axırları XX əsrin əvvəllərində intensiv şəkildə öyrənilməyə başlanmışdır.Y.A.Kantoroviç, P.O. Eforissi, A.E. Brusilovskiy, S.B. Poznışev və başqaları məhkəmə psixologiyasının müxtəlif problemlərinin açıqlanmasına cəhd göstərmişlər.

$\mathrm{Bu}$ ölkənin bəzi şəhər məhkəmələrində və prokurorluq orqanlarında məhkəmə psixologiyası üzrə daimi fəaliyyət göstərən elmi-praktiki seminarlar keçirilirdi.

Rus alimi M.N.Qernetin həbsxana psixologiyasına həsr olunmuş bir neçə əsəri onu təsdiq edir ki, bu sahədə böyük tədqiqatlar aparılırdı,hüquqi təcrübətə psixologiyanın rolu gündən günə artmağa başladı.

Sankt-Peterburqda A.F. Koni, Kiyevdə akademik V.M. Bexterev və başqaları psixo-nevroloji institutlarda bu sahədə tədqiqatlar aparmışlar.

Moskva şəhərinin quberniya prokurorluğunda xüsusi eksperimental laboratoriyada alim A.P.Luriya tərəfindən tədqiqatlar aparılırdı.Elmi tədqiqatlar həmçinin dövlət eksperimental psixologiya institutunda da həyata keçirilirdi.

Bunu da qeyd etmək lazımdır ki,məhkəmə psixologiyasının sərbəst elm kimi formalaşı fəaliyyətdə olması barədə elmi fikirlər təkcə hüquqşünaslar arasında deyil,həmçinin psixoloqlar arasında da təşəkkül tapmışdır.

İnsan fəaliyyətini öyrənmək məqsədilə 1930-cu ildə SSRİ-də keçirilən ümumittifaq qurultayda məhkəmə psixologiyasının problemləri müzakirə predmeti olmuşdur. "Psixoloqların davranış qurultayında" (Povedencheslyi s'ezd psikhologov) məhkəmə psixologiyası sahəsində ayrıca seksiya yaradılmışdı ki, bu sahədə üç əsas istiqamətin inkişaf etdirilməsinə diqqətin artırılması göstərilmişdir:kriminal-cinayətkarlığı və cinayətkarlığın öyrənilməsi,pentensiar cəza çəkənlərin davranışlarının və onlarla işləyən əməkdaşların şəxsi keyfiyyətlərinin öyrənilməsi və cinayət mühakimə fəaliyyətinin müxtəlif mərhələlərinin öyrənilməsi.

Lakin XX əsrin 30-cu illərinin ortalarında SSRİ-də baş verən hüquqi böhran nəticəsində psixologiyanın və hüquq sahələrinin bir-birini zənginləşdirməsi

employees of investigative, judicial and penitentiary authorities" and G. Tohun "Legal and criminal psychology" might be shown. 
prosesi dondurulmuşdur. $\mathrm{Bu}$ dövrdə yanlış olaraq məhkəmə psixologiyasının məhkəmə psixiatriya elmi ilə birləşməsinə cəhd göstərilirdi.

Yalnız XX əsrin 60-cı illərində məhkəmə psixologiyası elminin tədqiqinə diqqət yetirilməyə başlandı və hüquq ədəbiyyatında hüquqi problemlərin psixoloji əsaslandırılması məsələlərinin tədqiqinə rast gəlinirdi. ${ }^{8}$

$\mathrm{Bu}$ sferada bəzi rus alimlərinin və praktiki işçilərin irəli sürdükləri fikirlər müəyyən maraq doğurur. Belə ki, onlar öz yazılı mənbələrində məhkəmə psixologiyasından cinayət-mühakimə icraatında istifadə edilməsinin zəruriliyini qeyd edirdilər.

$\mathrm{Bu}$ zaman alimlərin əsərlərində "istintaq taktikasının inkişafı,kriminalistikanın psixologiyadan istifadə edilməsindən bilavasitə asılıdır” kimi fikirlər mərkəzi yer tuturdu.

Sonradan ayr1-ayrı istintaq hərəkətlərinin keçirilməsində, məhkəmə sübutları nəzəriyyəsində psixoloji biliklərdən istifadə problemləri tədqiqat obyektlərinə çevrildi və ciddi elmi əsərlər təşəkkül tapdı.

Cinayət hüququnun inkişafı, kriminologiyanın və cəza-icra hüququnun yaranması psixoloji biliklərdən hüquqi sahələrdə istifadə edilməsinə böyük təkan verdi.SSRİ-nin ali və orta hüquq tədris müəssisələrində "Məhkəmə psixologiyası" fənni tədris olunmağa başladi.

Beləliklə, nəhayət sovet məkanında "hüquq-psixologiya" elmi yarandı və onun müxtəlif istiqamətləri formalaşmağa başladı.Müxtəlifdərsliklər, dərs vəsaitləri nəşr olundu.

XX əsrin 90-cı illəridən başlayaraq, Azərbaycan öz dövlət müstəqilliyini bərpa etdikdən sonra, psixologiya elminin nailiyyətlərindən hüquq təcrübəsində istifadə edilməsi və inkişafına təkan verildi. B.H. Oliyev "Cinayət və mülki məhkəmə prosesində psixoloji ekspertiza problemləri” monoqrafiyasinda bu sahə ətraflı açıqlamışdır.

Hesab edirik ki,inteqrativ kriminalistik taktikanın struktur elementlərindən istifadə edilməsinin psixoloji mexanizminin mahiyyətinin öyrənilməsi,

\footnotetext{
${ }^{8}$ Vasilyev A.N. and others "Planning of investigation of crimes", "Inspection of occurrence" and others.
} 
cinayətkarlıqla müvəffəqiyyətlə mübarizə aparılması üçün şərait yarada bilər. Çünki həmin fəaliyyətdə müxtəlif subyektlər və təzahürlər ünsiyyətdə olurlar. Məsələn, hüquq-mühafizə orqanlarının nümayəndələri və cinayət törətmişşəxslər arasında olan münasibətlər.

Eləcə də inteqrativ kriminalistik taktikanın struktur elementlərinin cinayətkarlıqla mübarizədə istifadə edilməsinin psixoloji mexanizminin dərindən öyrənilməsi, subyektlər və obyektlər arasında yaranan ünsiyyətin nəticələrinin səmərəliliyinə bilavasitə təsir göstərə bilər. Ona görə də cinayət mühakimə icraat1 fəaliyyətinin psixoloji strukturunun mahiyyətini dərindən araşdırmaq məqsədə müvafiqdir. Hüquq-mühafizə fəaliyyəti sahəsində olan hər bir fəaliyyətin özünə məxsus psixi keyfiyyətlərə,vərdişlərə və təzahürlərə malik olduğundan, hər bir fəaliyyətin psixoloji strukturunu öyrənmək vacibdir.

Psixoloji fəaliyyətin strukturunun mahiyyətinin açıqlanması həmin fəaliyyətin xüsusiyyətlərinin daha dərindən və tam dərk edilib, onun həyata keçirilməsinin mükəmməl hazırlanmasına şərait yaradır.Mürəkkəb və yüksək cavabdehlik tələb edən məhkəmə mühakimə fəaliyyətinə bu daha çox vacibdir.

Müstəntiq fəaliyyətinin psixoloji strukturunun əsas və müəyyənedici komponenti, onun dərketmə prosesidir. $\mathrm{O}$, törədilmiş cinayət üzrə həqiqəti müəyyən etmək məqsədilə zəruri faktları əldə edir.Beləliklə də, keçmişdə baş vermiş hadisəni təhlil edərək, həmin fakta münasibəti olan şəxslərlə ünsiyyətə girir, cinayət törətmiş şəxslərin aşkar edilməsi üçün müvafiq tədbirlər görür. Deməli,yalnız ibtidai araşdırma zamanı keçmişdə baş vermiş hadisənin modeli yaradilır.

Cinayət mühakimə icraatının ibtidai araşdırma mərhələsində dərketmə prosesinin bütün xüsusiyytələri vəhdət şəklində özlərini realizə edir. Faktları toplayarkən, müstəntiq öz fəaliyytəinin nə ilə nəticələnəcəyini əvvəlcədən görmür, həm də törədilmiş hadisənin əqli modelini tam yarada bilmir. Dərketmə fəaliyyətinin bu xüsusiyyəti, sübutları toplayarkən və onları qiymətləndirərkən müstəntiqi müxtəlif çətinliklərlə üzləşməyə vadar edir, ona görə də cinayət faktını araşdıran əməkdaşlar müxtəlif fərziyyələr irəli sürürlər,onların yoxlanması,aşkar 
edilmiş faktların təbiətini,onların bir-birilə əlaqəsini,asılılığını müəyyən etmək üçün birgə kompleks tədbirlər görürlər.

Başqa növ fəaliyyətlərdən fərqli olaraq, ibtidai araşdırma fəaliyyətinin psixoloji strukturuna aşağıdakı elementlər daxildir:

1.Dərketmə fəaliyyətinin xüsusiyyətləri

2.Konstruktiv fəaliyyətinin xüsusiyyətləri

3.İbtidai araşdırmada tərbiyəedici fəaliyyət

4.Müstəntiqin peşəkar-psixoloji keyfiyyətləri

5.İstintaq hərəkətlərinin strukturunun psixoloji elementləri

6. İbtidai araşdırma iştirakçılarının psixoloji xüsusiyyətləri

7.İstintaq hərəkətlərinin psixoloji xarakteristikas1

Cinayətlərin açılmasında və araşdırılmasında həmin elementlərin təcrübi əhəmiyyəti ayrıca tədqiqat mövzusudur.

Beləliklə, cinayət işi üzrə icraat aparan zaman müstəntiq tərəfindən psixologiya elminin müddəalarını bilməsi və onlardan bacarıqla istifadə etməsi mühüm əhəmiyyət kəsb edir.

\section{References}

1. Aliyev B.H. Cinayet ve mulki prosesde mehkeme-psikholoji ekpertiza problemleri [Issues of forensic psychological expert examination in criminal and civil process]. Baku, 1996, 200 p.

2. Dulov A.V. Sudebnaya psikhologiya [Forensic psychology]. Minsk, 1970. $464 \mathrm{p}$.

3. Korneeva L.M., Vasilev A.N. Taktika doprosa pri rassledovanii prestupleniy [Tactics of interrogation at investigation of crimes]. Moscow, 1970, $720 \mathrm{p}$.

4. Luzgin N.M. Rassledovanie kak protsess poznaniya [Investigation like a process of cognition]. Moscow, 1969, $178 \mathrm{p}$. 
5. Ratinov N.A. Sudebnaya psikhologiya dlya sledovateley [Forensic psychology for investigators]. Moscow, 1967, 290 p.

6. Shiraliyeva S.J. Kontseptual'nyie osnovy ispol'zovaniay integrativnoy kriminalisticheskoy taktiki pri rassledovanii prestupleniy [Conceptual bases of usage of integrative criminalistical tactics at investigation of crimes]. $\mathrm{PhD}$ in Law Diss. Abstract. Baku, 2006, 22 p. 